\title{
Semantic differential as a method in empirical investigation of Self-Image as father
}

\author{
Robert Manerov ${ }^{1}$, Kristina Manerova ${ }^{2}$ \\ ${ }^{1}$ Department of Psychology and Pedagogy, University of Emercom, Russia \\ ${ }^{2}$ Department of German Linguistics, Saint Petersburg University, Russia \\ https://doi.org/10.36505/ExLing-2016/07/0024/000283
}

\begin{abstract}
In our current study psychosemantics principles are used in the development of own method "Father Image", based on the method of semantic differential of Ch. Osgood. Following images are conceptual constructs in the study: Father Image, Self-Image as a father, Real Self-image as a father, Constructive Self-image as a father. The semantic differential provides a measure of 47 signs of the "Father Image", expressed by bipolar seven-point scale. The 47-sign scales are named with antonym pairs of Russian adjectives and contradictional propositions, which were composed by the modified method of M. Kuhn and T. McPartland and then evaluated by groups of single and married male probationers with and without kids
\end{abstract}

Key words: semantic differential, self-Image, father Image

\section{Introduction}

The study was based on the psychosemantic approach (cf. V. Petrenko, A. Shmelev, Ch. Osgood, J. Kelly et al.). We used psychosemantic principles to develop our own method called "Father image' semantic differential" and to interpret the findings. Currently, the main goals of the psychosemantic approach include building and reconstruction of the individual value system through which the subject perceives the world, other people and himself. Our own "'Father image' semantic differential" method was based on Osgood's semantic differential, which is a part of experimental psychosemantics.

\section{Methodology and results}

The object of study was evaluated by subjects based on 47 bi-polar seven-point scales (Table 1). Each scale was built on the principle of opposition of a pair of antonyms. The concepts of our study:

Father image - a set of views on paternal roles, functions and qualities that reflect the sociocultural, gender, age-related attitudes, traditions and stereotypes, as well as one's personal experiences with one's father.

Self-Image as a father - a set of man's views on his own paternal needs, roles, functions and qualities that reflect the sociocultural, gender, agerelated attitudes, traditions and stereotypes towards a man as a father.

ExLing 2016: Proceedings of $7^{\text {th }}$ Tutorial and Research Workshop on Experimental Linguistics, 27 June - 2 July 2016, Saint Petersburg, Russia 


\section{R. Manerov, K. Manerova}

Table 1. "Father image" semantic differential.

\begin{tabular}{|c|c|c|c|}
\hline 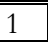 & Intelligent & 3210123 & Unintelligent \\
\hline 2 & Hostile & 3210123 & Friendly \\
\hline 3 & Possessing authority & 3210123 & Lacking authority \\
\hline 4 & Unsympathetic & 3210123 & Sympathetic \\
\hline 5 & Caring & 3210123 & Not caring \\
\hline 6 & Repulsive & 3210123 & Charming \\
\hline 7 & Can be trusted & 3210123 & Cannot be trusted \\
\hline 8 & Apathetic & 3210123 & Energetic \\
\hline 9 & Teaches the child a lot of things & 3210123 & Does not teach the child much \\
\hline 10 & Strict & 3210123 & Gentle \\
\hline 11 & Decent & 3210123 & Indecent \\
\hline 12 & Able to make sacrifices & 3210123 & Not able to make sacrifices \\
\hline 13 & Insincere & 3210123 & Sincere \\
\hline 14 & Supports the family & 3210123 & Does not support the family \\
\hline 15 & Unfair & 3210123 & Fair \\
\hline 16 & Worthy of emulation & 3210123 & Not worthy of emulation \\
\hline 17 & Indifferent & 3210123 & Compassionate \\
\hline 18 & Faithful & 3210123 & Unfaithful \\
\hline 19 & Pessimistic & 3210123 & Optimistic \\
\hline 20 & Loved & 3210123 & Hated \\
\hline 21 & Insecure & 3210123 & Confident \\
\hline 22 & Makes the child proud & 3210123 & Does not make the child proud \\
\hline 23 & Rude & 3210123 & Gentle \\
\hline 24 & Raises the child & 3210123 & Does not raise the child \\
\hline 25 & Unhappy & 3210123 & Happy \\
\hline 26 & Close & 3210123 & Distant \\
\hline 27 & Vicious & 3210123 & Virtuous \\
\hline 28 & Children love him & 3210123 & Children don't love him \\
\hline 29 & Irritable & 3210123 & Cool-headed \\
\hline 30 & A family man & 3210123 & Not a family man \\
\hline 31 & Passive & 3210123 & Active \\
\hline 32 & Able to protect & 3210123 & Not able to protect \\
\hline 33 & Selfish & 3210123 & Altruistic \\
\hline 34 & Considerate & 3210123 & Inconsiderate \\
\hline 35 & Weak & 3210123 & Strong \\
\hline 36 & Irresponsible & 3210123 & Responsible \\
\hline 37 & His love has to be earned & 3210123 & His love does not have to be earned \\
\hline 38 & Lazy & 3210123 & Hardworking \\
\hline 39 & Educated & 3210123 & Uneducated \\
\hline 40 & Despised & 3210123 & Respected \\
\hline 41 & Reliable & 3210123 & Unreliable \\
\hline 42 & Authoritarian & 3210123 & Democratic \\
\hline 43 & Loving & 3210123 & Not loving \\
\hline 44 & Sad & 3210123 & Cheerful \\
\hline 45 & Determined & 3210123 & Free-floating \\
\hline 46 & Angry & 3210123 & Kind \\
\hline 47 & Spends much time with the child & 3210123 & Not spending much time with the child \\
\hline
\end{tabular}


Real Self-Image as a father - a set of man's views on his actual paternal needs, roles, functions and qualities, on what kind of father he actually is.

Constructive Self-Image as a father - a set of man's views on paternal needs, roles, functions and qualities which reflects what kind of father the man aspires to become and sees himself becoming in the future, as well as the obstacles to the achievement of the said.

Table 2. Factors of the real and constructive Self-Image as a father in men sith different paternal and marital status.

\begin{tabular}{|c|c|c|c|c|}
\hline \multirow{3}{*}{$\begin{array}{l}\text { SELF-IMAGE } \\
\text { AS FATHER }\end{array}$} & \multirow{3}{*}{ \# } & \multicolumn{3}{|l|}{ Groups of men } \\
\hline & & Married fathers & $\begin{array}{l}\text { Married men } \\
\text { without children }\end{array}$ & $\begin{array}{l}\text { Unmarried men } \\
\text { without children }\end{array}$ \\
\hline & & \multicolumn{3}{|l|}{ Factors } \\
\hline \multirow{5}{*}{$\begin{array}{l}\mathrm{R} \\
\mathrm{E} \\
\mathrm{A} \\
\mathrm{L}\end{array}$} & 1 & $\begin{array}{l}\text { Morality } \\
\text { (factor power } 0,178 \text { ) }\end{array}$ & $\mid \begin{array}{l}\text { Syncretism } \\
\text { (factor power } 0,180)\end{array}$ & $\mid \begin{array}{l}\text { Syncretism } \\
\text { (factor power } 0,181 \text { ) }\end{array}$ \\
\hline & 2 & $\begin{array}{l}\text { The object of love } \\
\text { (factor power } 0,139 \text { ) }\end{array}$ & $\begin{array}{l}\text { Caring and } \\
\text { trustworthy teacher } \\
\text { (factor power } 0,145) \\
\end{array}$ & $\begin{array}{l}\text { The object of pride } \\
\text { and love } \\
\text { (factor power } 0,158 \text { ) }\end{array}$ \\
\hline & 3 & $\begin{array}{l}\text { Social Activity } \\
\text { (factor power } 0,097 \text { ) }\end{array}$ & $\begin{array}{l}\text { The object of love } \\
\text { (factor power } 0,124 \text { ) }\end{array}$ & $\begin{array}{l}\text { Strong Personality } \\
\text { (factor power } 0,137 \text { ) }\end{array}$ \\
\hline & 4 & $\begin{array}{l}\text { Caring and } \\
\text { trustworthy teacher } \\
\text { (factor power } 0,071 \text { ) } \\
\end{array}$ & $\begin{array}{l}\text { Social Activity } \\
\text { (factor power 0,089 }\end{array}$ & $\begin{array}{l}\text { Social Activity } \\
\text { (factor power 0,086) }\end{array}$ \\
\hline & 5 & $\begin{array}{l}\text { Kindness } \\
\text { (factor power } 0,057 \text { ) }\end{array}$ & $\begin{array}{l}\text { Mentor } \\
\text { (factor power } 0,065 \text { ) }\end{array}$ & $\begin{array}{l}\text { Democratic } \\
\text { (factor power } 0,055 \text { ) }\end{array}$ \\
\hline \multirow{6}{*}{$\begin{array}{l}\mathrm{C} \\
\mathrm{O} \\
\mathrm{N} \\
\mathrm{S} \\
\mathrm{T} \\
\mathrm{R} \\
\mathrm{U} \\
\mathrm{C} \\
\mathrm{T} \\
\mathrm{I} \\
\mathrm{V}\end{array}$} & 1 & $\begin{array}{l}\text { Syncretism } \\
\text { (factor power } 0,220 \text { ) }\end{array}$ & $\begin{array}{l}\text { Syncretism } \\
(\text { factor power } 0,213)\end{array}$ & $\begin{array}{l}\text { Trustworthy Teacher } \\
\text { (factor power } 0,168 \text { ) }\end{array}$ \\
\hline & 2 & $\begin{array}{l}\text { Morality } \\
\text { (factor power } 0,107 \text { ) }\end{array}$ & $\begin{array}{l}\text { Trustworthy Teacher } \\
\text { (factor power } 0,125 \text { ) }\end{array}$ & $\begin{array}{l}\text { Empathetic } \\
\text { (factor power } 0,166)\end{array}$ \\
\hline & 3 & 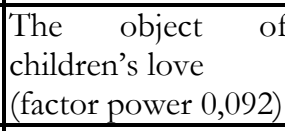 & $\begin{array}{l}\text { The subject of love } \\
\text { (factor power } 0,114 \text { ) }\end{array}$ & $\begin{array}{l}\text { Defender } \\
\text { (factor power 0,096) }\end{array}$ \\
\hline & 4 & $\begin{array}{l}\text { Social Activity } \\
\text { (factor power } 0,057 \text { ) }\end{array}$ & $\begin{array}{l}\text { Material support } \\
\text { (factor power } 0,102)\end{array}$ & $\begin{array}{l}\text { The object of pride } \\
\text { (factor power } 0,095 \text { ) }\end{array}$ \\
\hline & 5 & $\begin{array}{l}\text { Integrity } \\
\text { (factor power } 0,047 \text { ) }\end{array}$ & $\begin{array}{l}\text { Morality } \\
\text { (factor power } 0,096)\end{array}$ & $\begin{array}{l}\text { Social Activity } \\
\text { (factor power } 0,081 \text { ) }\end{array}$ \\
\hline & 6 & & $\begin{array}{l}\text { The object of pride } \\
\text { (factor power } 0,079 \text { ) }\end{array}$ & $\begin{array}{l}\text { Material support } \\
\text { (factor power } 0,066)\end{array}$ \\
\hline
\end{tabular}

In order to identify the structure of the real and constructive SelfImage as a father in men with different paternal and marital status, we 
carried out factorization of semantic differential scales. The scales were arranged in semantic factor groups. The factorization was carried out separately for all three groups of subjects, consecutively for the real and constructive images (Table 2).

\section{Conclusions}

A comparative analysis of the six factor structures of real and constructive Self-Image as a father in three groups of men led us to the following conclusions.

In both groups of men without children the constructive image is more geared towards the child and the family than the real one. The constructive image, unlike the real image, includes the "Supports the family" characteristic, which is not pronounced in the real fathers' group. It is likely that for most men who have not become fathers yet the issue of providing for the family becomes the central one in whether to have a child or not.

The real Self-Image as a father in married fathers is much more realistic and moderate than in the two groups of men without children, while the constructive (in many ways, ideal) father for them is a tentative model, distant from the real requirements and only partially realized in practice, as evidenced by the fathers' real experience.

The application of linguistically determined semantic differential method with subsequent factorization and quantitative assessment is justified in psychological research.

\section{References}

Manerov, R.V. 2013. The Self-Image as a father in the Men-Self-Concept. Thesis of Kandidate of Psychology Science, Herzen State Pedagogical University of Russia, URL: http:/ / elibrary.ru/item.asp?id=22372944 (in Russian).

Manerov, R.V., Posokhova, S.T. 2012. The Factor analysis structure of the Self-Image as a father by men with different paternal and marital status. In: A young scientist in the modern science world: new aspects of the scientific search. - L\&L Publishing, 189-197 (in Russian).

Manerov, R.V., Posokhova, S.T., Lippo, S.V. 2008. The father image and the personal self-actualization In: Herald of St. Petersburg University. Psychology, Sociology, Pedagogy, Nr. 3, 23-30 (in Russian).

Manerov, V. Kh. 2012. The experience of semantic differential approach in the research of the audio perception of verbal message. In: Traditions and innovations in Psychology in Russia. Proceedings of the International conference, dedicated to 215th Anniversary of the Herzen State Pedagogical University of Russia, 450-455 (in Russian). 